\title{
Multiple Intelligences Of Students At Jordanian Universities
}

\author{
Oraib Hmoud Ali Al-Faoury, Philadelphai University, Jordan \\ Abdalla Khataybeh, Yarmouk University, Jordan \\ Kholoud Al-Sheikh, King AbdulAziz University, Saudi Arabia
}

\begin{abstract}
The present study aimed at investigating different intelligence types among Jordanian students at different public and private universities in Jordan. To achieve such aim, it sought to identify and rank multiple intelligences that characterize students at Jordanian universities, and to identify and rank the differences in multiple intelligences according to some variables: the gender, university (public or private), the students' averages, the students' specializations and the academic year.
\end{abstract}

This study has used a survey as an instrument of collecting data. The study sample consisted of (1436) students from the University of Jordan, Yarmouk University, Al-Hashemaya University, the University of Sciences and Technology, Petra University, Al-Zarqa University, Amman Arab University, Al-Isra' University, Al-Zaitunah University and Philadelphia University. The students estimated their own IQ scores on each of Gardner's 7 multiple intelligences: logica入 mathematical IQ, musical IQ, interpersonal IQ, Kinesthetic IQ, Intra-personal IQ, Linguistic IQ and Spatial IQ. After analyzing the data, T-Test indicated that interpersonal intelligence is the highest and the most common intelligence among Jordanian students. Following are Intrapersonal, Kinesthetic, Linguistic, Spatial, logica入 mathematical, and musical, respectively.

There were significant differences among Jordanian students in the linguistic and interpersonal intelligence in favor of the females. There were significant differences in the logical intelligences in favor of the governmental universities. There were no significant differences in the multiple intelligences that can be attributed to the averages of the students. There were significant differences in the musical intelligence in favor of the graduates.

Keywords: Multiple Intelligences; IQ Scores; Jordanian Universities; Jordanian Students

\section{INTRODUCTION}

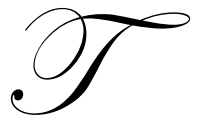

he topic of intelligence has been hotly debated in psychology. Traditionally, intelligence is defined in terms of intelligence quotient (IQ) that measures a narrow range of verbal/ linguistic and logical/mathematical abilities a person has. Gardner (1993a), however, in his book entitled "Frames of Mind: the Theory of Multiple Intelligences" has altered this traditional definition by providing an alternative definition of intelligence. Gardner (ibid) has defined intelligence as "the ability to solve problems or to create products that are valued within one or more cultural settings" (P.11). He reviewed hundreds of studies before assessing all candidates on the basis of eight criteria: the potential of isolation by brain damage; an evolutionary history and evolutionary plausibility; and identifiable core operation or a set of operations; susceptibility to encoding in a symbol system; a distinct developmental history; the existence of savants, prodigies, and other exceptional people; support from experimental psychological tasks, and support from psychometric findings. Thus, his concept of intelligences expanded the parameters of intelligent scope to include a diversity of human abilities.

This theory suggests that each individual has a unique combination of the seven intelligences. Gardner specifies seven intelligences and argues that linguistic/verbal and logical mathematical intelligences are those typically valued in educational settings. Linguistic intelligence refers to the sensitivity to the spoken and written 
language and the ability to learn languages. Logical-mathematical intelligence refers to the capacity of analyzing problems logically, solving mathematical problems, and investigating issues scientifically. These two types of intelligence dominate intelligence tests.

Three other multiple intelligences are art-based: musical intelligence, bodily-kinesthetic intelligence, and spatial intelligence. The first one refers to the ability to sense the rhythm, the pitch and the melody, and it includes skills such as recognizing simple songs and varying speed, tempo, and rhythm in simple melodies. The second refers to the use of the whole or parts of the body to solve problems or to fashion products. The third refers to the ability to recognize and manipulate patterns in space.

The last intelligences are: interpersonal intelligence and intrapersonal intelligence. The former refers to the capacity of understanding other people's intentions, motivations and desires and working effectively with them. The latter refers to the ability of understanding oneself, including one's weaknesses, strengths, moods, intentions and desires.

In his later book, Gardner (1999b) defines intelligence as a "biopsychological potential to process information that can be activated in a cultural setting to solve problems or create products that are of value in a culture" (pp. 33-34). He elaborates on the issue in question and adds another type of intelligence, namely naturalistic intelligence. He defines it as the "expertise in the recognition and classification of the numerous species - the flora and fauna - of his or her environment" (p. 43). He presented spiritual and existential intelligences. The former is defined as the ability to master a set of diffuse and abstract concepts about being, but also mastering the craft of altering one's consciousness in attaining a certain state of being. The latter is yet more difficult to define, refers to "the capacity to locate oneself with respect to the furthest reaches of the cosmos - the infinite and infinitesimal - and the related capacity to locate oneself with respect to such existential features of the human condition as the significance of life, the meaning of death, the ultimate fate of the physical and the psychological worlds and such profound experiences as love of another person or total immersion in a work of art" (p. 61).

It seems that there are various individual differences in human being's intelligences. Gardener (1983) mentions that each person possesses all the eight intelligences, but they function uniquely. For example, a person may be outstanding in math but poor in grammar and another person may excel in arts but be poor in mathematics, and this fact became Gardner's basis for the Multiple Intelligence theory.

Gardener (2004) explains that every individual is born with a certain intelligence or potential intelligence, which is difficult to be changed. He adds that Psychologists can assess one's intelligence (IQ) by means of shortanswer tests and other purer measures such as the time it takes to react to a flashing light or the presence of a certain pattern of brain waves. Gardner bases his description of intelligence on a wide set of sources which, according to him, have never been considered before. These sources deal with the development of different kind of skills that are found in a normal child and the information on ways these skills can break down under such conditions as brain damage. Gardner studies the information on normal development, breakdowns, and the special populations (prodigies, autistic children, learning disabilities, all who exhibit alternative profiles).

Wallace (2010) claims that the study of exceptional individuals has influenced Gardner to develop his idea of MI (multiple intelligences). He adds that it can be observed that some people are capable of calculating multidigit numbers in their heads or can play a musical composition after hearing the music once. He also refers to savants who demonstrate amazing abilities in intelligence while performing very poorly in another.

It remains a question whether or not MI theory is entirely supported from neural system evidence. Waterhouse (2006) argues that this theory fail to be supported by empirical evidence or testable psychological subcomponents for each of the intelligences. On the other hand, Chen (2004) indicates that Gardner's criteria for defining intelligence as a separate intelligence are valid and derived from a comprehensive, thorough, and systematic review of empirical data from studies in biology, neuropsychology, developmental psychology and cultural anthropology. He maintains that MI theory can be qualified as scientific theory because intelligence is not a tangible, measurable object and the theory's value is in its contribution to educational and practice but not because it meets any particular set of any scientific principle. 
Gunst (2004) asserts that in the 1990, educators began to recognize the viability of this theory. He adds that in the last decade MI was introduced, applied, studied and assessed in various projects and schools. Many researchers highlight the importance of MI theory. Eisner (2004) emphasizes the effective role of this theory in the individualization of learning. Nataša (2010) states that this theory offers a better understanding of students' intelligence and a greater appreciation of their strengths. She adds that MI theory has been considered a milestone for educational innovation not only in the United States but throughout the world that forced educators not only to come to a recognition of the diversity of the learners in their learning styles and learning potentials but also to appreciate the development of learning strategies on the part of the learners in the form of "individualized instruction" and "independent learning".

Other researchers highlight the effective role teachers are called to play with relevant to the premise of this theory. Fink (1991) argues that if the teacher is to implement MI theory, has to discover and nurture intelligences for a variety of students and to take a tremendous amount of energy and collaboration in order to reach to the excitement, creativity and learning outcomes. Eksi (2000) emphasizes the responsibility of the teachers in implementing activities that call upon all these intelligences in order to reach to every young learner in the classroom.

\section{STATEMENT OF THE PROBLEM}

Nowadays, MI theory is assuming a very important place in the recognition of the diversity of the learners in their learning styles all over the world. This is due to the fact that it helps educationalists, teachers and learners prepare successfully for "individualized instruction". Consequently, many researchers stress the importance of empowering students with recognition of their intelligences in order to enhance and develop their learning (Gürbüz \& Gürbüz 2010, Nataša 2010, Wu and Alrabah 2009, Netoa, Ruiza \& Furnhamb 2008). Thus, it seems necessary to recognize the Jordanian students' intelligences in order to consider them when designing for the teaching and learning process to develop the students' learning performance.

\section{PURPOSES OF THE STUDY}

The purposes of the study were twofold:

(1) To identify and rank the multiple intelligences of students at Jordanian universities.

(2) To identify and rank the differences in multiple intelligences according to the following variables:

a. gender

b. university ( public or private)

c. students' averages

d. specializations of the students.

e. the academic year students are enrolled in

\section{SIGNIFICANCE OF THE STUDY}

This study is important because it will help the educationalists in Jordan to recognize the most common types of intelligences among students. Accordingly, they might be able to modify their pedagogy to suit students' different types of intelligences as to help them to be autonomous learners. The present study might raise the awareness of teachers and students about the issue in question and provide better understanding of individual differences when it comes to students' strengths and abilities. It is hoped that the present study would address those differences to help the individual students develop their potential.

\section{LIMITATIONS OF THE STUDY}

This study was limited to the followings:

(1) The participants of this study were limited to all Jordanian students in public and private universities in the north and middle of Jordan. 
(2) The multiple intelligences which were included in this study were seven which included logical $\backslash$ mathematical, musical, interpersonal, Physical, Intra-personal, Linguistic and Spatial intelligences.

\section{REVIEW OF THE LITERATURE}

Netoa, Ruiza and Furnhamb (2008) investigate the relationship among sex, attitude toward intelligence, and self-estimation of multiple intelligences for self and parents among Portuguese adolescents in secondary schools. Two hundred and forty-two adolescents estimated their own and their parents' IQ scores on each of Gardner's 10 multiple intelligences: verbal (linguistic), logical (mathematical), spatial, musical, body-kinesthetic, interpersonal, intrapersonal, existential, spiritual, and naturalistic. They also answered six simple questions concerning intelligence and intelligence tests. There were various sex differences in self-estimated IQ: males rated themselves higher on overall, mathematical, spatial, intrapersonal, spiritual, and naturalistic IQ compared with females. Multiple regressions indicated that verbal, logical, and intrapersonal intelligence were significant predictors for self and parents overall IQ estimations. Factor analysis of the tenth, the eight, and the seventh self-estimates scores did not confirm Gardner's classification of multiple intelligences. Males were more likely to believe in sex differences in intelligence than females. Results were discussed in terms of the growing literature in the self-estimated intelligence, as well as limitations of that study.

Wu and Alrabah (2009) conduct a study based on MI theory. The purpose of their study was to relate the findings of a survey of learning styles and multiple intelligences that was distributed among two different cultural groups of Freshman-level EFL students in Taiwan and Kuwait in order to confirm its consistency for developing teaching techniques appropriate for each group's general profiles. Data collection consisted of a survey adopted from two standardized instruments. Part one of the survey targeted the students' preferred learning styles and part two focused on multiple intelligences. Data analysis identified the dominant learning styles and multiple intelligences in each group. Implications were drawn for conducting other cross-cultural studies in EFL settings in order to develop teaching techniques that accommodate each cultural group and to design teaching tasks and activities that expand the two groups' present learning styles and intelligences.

Yuen and Furnham (2005) conduct a study concerning MI. A total of 378 Hong Kong adolescents were asked to estimate their own and their parents' IQ score on each of Gardner's ten multiple intelligences: verbal/linguistic, logical/mathematical, spatial, musical, body-kinesthetic, interpersonal, intrapersonal, existential, spiritual and naturalistic. They answered three simple questions concerning intelligence and intelligence tests. Sex differences were revealed in eight of the ten self-estimates except for verbal and interpersonal. Male participants gave higher scores than female participants. Factor analyses of the ten dimensions yielded a two interpretable- factor solution: personal-social-spiritual intelligence and academic-arts-kinesthetic intelligence. There were consistent sex differences in the estimates of the academic-arts- kinesthetic intelligence factor for oneself, but not for parents, while there were sex differences in the estimates of the personal-social-spiritual intelligence factor for oneself and for mother, but not for father. The two factor scores were predicted by both gender and belief about intelligence.

Loori (2005) describes a study of 90 international students learning second languages at three American universities, to determine whether or not their gender influences their preference for multiple intelligences. A number of studies on learning style have suggested that males are more kinesthetic and peer-oriented in their learning styles than females, who were more persistent and responsible. One study explored the differences between males and females in terms of multiple intelligences, with Loori (2005) seeking to extend these findings in language learning.

In general, studies on intelligence have revealed that males tend to rate their

intelligence level as higher than females, while, with regard to Gardner's MI, males "showed higher ratings than the female participants did in logical/mathematical and spatial intelligence" (Loori, p. 79). Loori (2005) utilizes the Teele Inventory for Multiple Intelligences to determine if male or female international ESL learners had different multiple intelligence preferences. The findings indicated that "male and female ESL students in the United States of America differ significantly in some of their preferred intelligences," with males showing a slightly higher preference for logical/mathematical intelligence and females favoring intrapersonal intelligence. 
Bas (2010) investigates the effects of multiple intelligences-based teaching methods and traditional foreign language-teaching methods on students' academic achievement and their attitude towards English lesson. The study was carried out in 2008 - 2009 education-instruction year in Boruktolu Secondary School and Şeyh Şamil Secondary School, Meram, Konya. The study has revealed that multiple intelligences approach activities were more effective in the positive development of the students' attitudes. A significant difference was observed between the final grades of the experimental group and the control group. It was found that the former group scored higher than the latter. At the end of the study, it has been revealed that the students taught by methods based on multiple intelligence theory are more successful and highly motivated than those students taught by traditional foreign language teaching methods.

Many studies have revealed that the implementation of the MI theory could make very positive contributions to individual's recognition of intelligence self-estimate. Netoa, Ruiza and Furnhamb (2008) have found that males were more likely to believe in sex differences in intelligence than females. Wu and Alrabah (2009) have identified the multiple intelligences in their groups. Yuen and Furnham (2005) have found that there were consistent sex differences in the estimates of the academic-arts- kinesthetic intelligence factor for oneself, but not for parents, while there were sex differences in the estimates of the personal-social-spiritual intelligence factor for oneself and for mother, but not for father. Other studies have revealed the positive effect of applying MI theory on students' achievement. Baş, (2010), Şahin, Öngören and Çokadar (2010) have found that students when being taught by methods based on MI are more successful and highly motivated than students taught by traditional foreign language teaching methods.

The present study aims at identifying university Jordanian students' multiple intelligences with relevance to many variables which include: gender, university, averages, specialization, and academic year. It seeks to examine if these variables influence the students' estimations of their multiple intelligences. In doing so, the present study might bridge a gap in the literature where these variables have not been investigated before.

\section{METHODOLOGY}

After reviewing the available instruments in the literature to fulfill the purpose of the study, the researcher adopted one survey instrument for measuring multiple intelligences. To ensure the soundness of the survey, extensive consideration paid to retain the same language that was used in the standardized survey instruments. Moreover, cross-checking provided additional confirmation about the reliability of the responses.

\section{PROCEDURE}

The (1436) participants of the study are undergraduates of different specializations at different public and private universities in Jordan. All the copies of the questionnaire used to conduct the study were carefully labeled (serially and according to the level of students). Accordingly, these labeled questionnaires were given to the randomly selected students whose names and serial numbers were already recorded on a 'research file'.

The participants were informed of the purpose of the study and that whatever information given is for academic research and so will be treated in confidence. As the questionnaires were administered, the serial numbers were also recorded against the names and serial numbers of those given the questionnaires.

It took no long time for the students (that were randomly selected) to fill and return the questionnaires. This is because the questionnaires were administered, filled and retrieved during classes. However, even though about (1516) copies of the questionnaire were given out to the sample, only (1436) copies were completely filled and found useful for analysis. The whole process took about (30) days only. The remaining copies were discarded because they were either not completely filled or were wrongly filled.

\section{DATA COLLECTION}

A survey is used in the present study to collect data about multiple intelligences. It was constructed and distributed in December, 2010 among the study sample in public and private universities in the north and middle of 
Jordan. The survey was distributed in the University of Jordan, Yarmouk University, Al-Hashemaya University, the University of Sciences and Technology, Petra University, Al-Zarqa University, Amman Arab University, Al-Isra' University, Al-Zaitunah University, and Philadelphia University.

\section{DATA ANALYSIS}

Once the items of the survey were scored, the points for each of the intelligences were totaled for each student by using the (SPSS) software program. ANOVA, T-Test and Post Hoc Tests also helped in determining the means, standard deviations, percentages and ranks for each of multiple intelligences.

\section{SAMPLE OF THE STUDY}

The sample of the study consisted of 1407 students ( 775 male and 620 female), 575 from public university and 832 from private universities, 432 from scientific stream and 939 from literary stream, 230 with poor GPA, 537 with good GPA and 266 with very good GPA, 295 first year students, $4312^{\text {nd }}$ year, $3263^{\text {rd }}$ year, $2254^{\text {th }}$ year and 72 $5^{\text {th }}$ year.

\section{FINDINGS AND THEIR DISCUSSION}

Below are the findings the study has yielded and their discussion. These finding presented in sequence according to the questions of the study as follows:

1. What are the multiple intelligences of students at Jordanian universities?

To answer the above question, the students' responses for each of the intelligences were analyzed. The mean scores and standard deviation of these responses were also analyzed. The results of the analysis revealed that interpersonal intelligence was the highest and the most common intelligence among Jordanian students. Following this intelligence are: intra-personal, kinesthetic, linguistic, spatial, logical mathematical, and musical, respectively.

Table 1: Means and Standard Deviation of the Students' Responses

\begin{tabular}{|c|c|c|c|c|c|c|}
\hline Types of Intelligence & Number & Minimum & Maximum & Mean & $\begin{array}{c}\text { Standard } \\
\text { Deviation }\end{array}$ & Rank \\
\hline Logical $\backslash$ Mathematical & 1436 & 1 & 10 & 6.35 & 1.777 & 6 \\
\hline Musical & 1436 & 1 & 10 & 6.04 & 1.948 & 7 \\
\hline Interpersonal & 1429 & 1 & 10 & 6.95 & 2.006 & 2 \\
\hline Physical or bodily kinesthetic & 1428 & 1 & 10 & 6.53 & 1.796 & 3 \\
\hline Spatial & 1428 & 1 & 10 & 6.43 & 1.804 & 5 \\
\hline Intra-personal & 1421 & 1 & 10 & 6.96 & 1.994 & 1 \\
\hline Linguistic & 1416 & 1 & 10 & 6.44 & 1.894 & 4 \\
\hline $\mathrm{Q}$ all & 1436 & 1 & 10 & 6.53 & 1.535 & \\
\hline
\end{tabular}

According to the findings above, the Intrapersonal Intelligence ranked the highest and this might indicate that the majority of students at Jordanian University understand themselves, know their individual needs, weaknesses, strengths, moods, intentions and desires. The highest rank of this intelligence might reflect the influence of some social variables in the Jordanian environment. Jordanian people tend to bring up their kids giving them the freedom to think, choose, and behave the way they like, however, within some constraints. This freedom might lead the students to develop a sense of responsibility and considering individual needs and interests. Thus, they grow up with a clear vision of their inner identity and deep understanding of themselves.

2. Are there any Statistical Significant Differences in Multiple Intelligences According to the Gender of the Students?

In order to find the differences in multiple intelligences according to the students' gender, T-Test was conducted. The results of analysis revealed that there are statistical significant differences in the Intra-personal and Linguistic intelligences of the students in favor of females. Table (2) shows the results of T-Test for the differences in the mean scores for the students in Multiple Intelligence Test according to their gender. 
Table 2: t-Test for the Differences in the Mean Scores for the Students' Intelligences According to their Gender

\begin{tabular}{|c|c|c|c|c|c|c|c|}
\hline \multicolumn{2}{|c|}{ Gender } & $\mathbf{N}$ & Mean & $\begin{array}{c}\text { Std. } \\
\text { Deviation }\end{array}$ & $\begin{array}{l}\text { Degree of } \\
\text { freedom }\end{array}$ & t-value & significance \\
\hline \begin{tabular}{l} 
Logical\} $\\
{\text { Mathematical }}$ & $\begin{array}{l}\text { Male } \\
\text { Female }\end{array}$ & $\begin{array}{l}775 \\
620 \\
\end{array}$ & $\begin{array}{l}6.37 \\
6.33 \\
\end{array}$ & $\begin{array}{l}1.708 \\
1.853 \\
\end{array}$ & 1393 & 0.425 & 0.67 \\
\hline Musical & $\begin{array}{l}\text { Male } \\
\text { Female }\end{array}$ & $\begin{array}{l}775 \\
620\end{array}$ & $\begin{array}{l}5.97 \\
6.13\end{array}$ & $\begin{array}{l}1.950 \\
1.959\end{array}$ & 1393 & $\begin{array}{l}-1.488 \\
\end{array}$ & 0.137 \\
\hline Interpersonal & $\begin{array}{l}\text { Male } \\
\text { Female }\end{array}$ & $\begin{array}{l}771 \\
618\end{array}$ & $\begin{array}{l}7.01 \\
6.89\end{array}$ & $\begin{array}{l}1.942 \\
2.090\end{array}$ & 1397 & 1.041 & 0.298 \\
\hline $\begin{array}{l}\text { Physical or bodily } \\
\text { Kinesthetic }\end{array}$ & $\begin{array}{l}\text { Male } \\
\text { Female }\end{array}$ & $\begin{array}{l}770 \\
618 \\
\end{array}$ & $\begin{array}{l}6.46 \\
6.64 \\
\end{array}$ & $\begin{array}{l}1.722 \\
1.889 \\
\end{array}$ & 1386 & -1.827 & 0.068 \\
\hline Spatial & $\begin{array}{l}\text { Male } \\
\text { Female }\end{array}$ & $\begin{array}{l}771 \\
618 \\
\end{array}$ & $\begin{array}{l}6.40 \\
6.47 \\
\end{array}$ & $\begin{array}{l}1.816 \\
1.803\end{array}$ & 1387 & -0.753 & 0.452 \\
\hline Intra-personal & $\begin{array}{l}\text { Male } \\
\text { Female }\end{array}$ & $\begin{array}{l}767 \\
615\end{array}$ & $\begin{array}{l}6.86 \\
7.09\end{array}$ & $\begin{array}{l}1.907 \\
2.102\end{array}$ & 1380 & -2.158 & 0.031 \\
\hline Linguistic & $\begin{array}{l}\text { Male } \\
\text { Female }\end{array}$ & $\begin{array}{l}763 \\
614 \\
\end{array}$ & $\begin{array}{l}6.35 \\
6.56 \\
\end{array}$ & $\begin{array}{l}1.845 \\
1.958 \\
\end{array}$ & 1375 & -2.084 & 0.037 \\
\hline $\mathrm{Q}$ all & $\begin{array}{l}\text { Male } \\
\text { Female }\end{array}$ & $\begin{array}{l}775 \\
620\end{array}$ & $\begin{array}{l}6.49 \\
6.59 \\
\end{array}$ & $\begin{array}{l}1.466 \\
1.622 \\
\end{array}$ & 1393 & -1.183 & 0.242 \\
\hline
\end{tabular}
\end{tabular}

It might be true to say that the female demonstrate higher level of intrapersonal and linguistic intelligence than males due to the fact that girls in the Jordanian society in particular and all Arab society in general tend to spend almost of their time with their mothers, helping them, talking to them, watching T.V, and chatting with their counterparts. However, boys almost tend to spend time out of home playing and may join their fathers in work, especially if they are not clerks. Consequently, the chance of spending much time talking and chatting given to the females might be the cause of developing their linguistic and intra-personal intelligence over males.

3. Are there any Statistical Significant Differences in Multiple Intelligences According to the University?

In order to find the differences in multiple intelligences according to the students' university, T-Test was conducted. The results of the analysis revealed that there are statistical significant differences in the logical $\backslash$ mathematical intelligence of the students in favor of the governmental university. Table (3) shows the results of TTest for the differences in the mean scores for the students in Multiple Intelligence Test according to their university.

Table (3): T-test for the Differences in the Mean Scores

for the Students' Responses According to the Type of the University.

\begin{tabular}{|c|c|c|c|c|c|c|c|}
\hline \multicolumn{2}{|l|}{ University } & $\mathbf{N}$ & Mean & Std. Deviation & Df & t-value & significant \\
\hline Logical\ & Public & 775 & 6.49 & 1.818 & .1405 & 2.467 & 0.014 \\
\hline Mathematical & Private & 832 & 6.26 & 1.731 & & & \\
\hline Musical & Public & 775 & 5.96 & 1.955 & 1405 & -1.500 & 0.134 \\
\hline & Private & 832 & 6.12 & 1.941 & & & \\
\hline Interpersonal & Public & 574 & 7.01 & 2.021 & 1399 & 0.597 & 0.550 \\
\hline & Private & 827 & 6.94 & 1.993 & & & \\
\hline Physical or bodily Kinesthetic & Public & 574 & 6.54 & 1.844 & 1398 & -0.051 & 0.958 \\
\hline & Private & 826 & 6.54 & 1.761 & & & \\
\hline Spatial & Public & 575 & 6.52 & 1.819 & 1396 & 1.584 & 0.113 \\
\hline & Private & 825 & 6.37 & 1.792 & & & \\
\hline Intra-personal & Public & 572 & 7.09 & 2.055 & 1392 & 1.923 & 0.055 \\
\hline & Private & 822 & 6.88 & 1.951 & & & \\
\hline Linguistic & Public & 570 & 6.57 & 1.934 & 1387 & 1.908 & 0.057 \\
\hline & Private & 819 & 6.37 & 1.863 & & & \\
\hline $\mathrm{Q}$ all & Public & 575 & 6.60 & 1.565 & 1405 & 1.160 & 0.248 \\
\hline & Private & 832 & 6.50 & 1.513 & & & \\
\hline
\end{tabular}


As the findings above revealed, we find that public university students outperform their counterparts in private university in concern with logical/mathematical intelligence. The reason behind this appears in that the public universities tend to admit students with high average and grades unlike private universities. Consequently, students in public universities develop their logical/mathematical skills more than those students in private universities. Furthermore, the academic system and regulations in public universities is more severe and strict than in private universities, the thing that may affect students' achievement and responsibility.

4. Are there any Statistical Significant Differences in Multiple Intelligences According to the Average?

In order to find the differences in multiple intelligences according to the students' average, analysis of covariance (ANOVA) was conducted. The results of the analysis revealed that there were no significant differences in the multiple intelligences that can be attributed to the averages of the students. Table (4) shows the results of ANOVA for the differences in the mean scores for the students in Multiple Intelligence Test according to their averages.

Table (4): ANOVA Analysis for the Differences in the Mean Scores for the Students Responses According to their GPA

\begin{tabular}{|c|c|c|c|c|c|c|}
\hline Domain & Source of variance & $\begin{array}{c}\text { Sum of } \\
\text { Squares }\end{array}$ & $\begin{array}{c}\text { Mean } \\
\text { Squares }\end{array}$ & df & F-value & Significance \\
\hline Logical /Mathematical & $\begin{array}{l}\text { Between Groups } \\
\text { Within Groups } \\
\text { Total }\end{array}$ & $\begin{array}{c}42.970 \\
3312.420 \\
3355.390\end{array}$ & $\begin{array}{c}14.323 \\
3.067 \\
--\end{array}$ & $\begin{array}{c}3 \\
1080 \\
1080\end{array}$ & 4.670 & 0.003 \\
\hline Musical & $\begin{array}{l}\text { Between Groups } \\
\text { Within Groups } \\
\text { Total }\end{array}$ & $\begin{array}{c}5.647 \\
4123.257 \\
4128.905 \\
\end{array}$ & $\begin{array}{l}1.882 \\
3.818\end{array}$ & $\begin{array}{c}3 \\
1080 \\
1083\end{array}$ & 0.493 & 0.687 \\
\hline Interpersonal & $\begin{array}{l}\text { Between Groups } \\
\text { Within Groups } \\
\text { Total }\end{array}$ & $\begin{array}{c}2.626 \\
4380.850 \\
4383.475 \\
\end{array}$ & $\begin{array}{l}0.875 \\
3.224\end{array}$ & $\begin{array}{c}3 \\
1073 \\
1076 \\
\end{array}$ & 0.215 & 0.886 \\
\hline Physical/Bodily Kinetics & $\begin{array}{l}\text { Between Groups } \\
\text { Within Groups } \\
\text { Total }\end{array}$ & $\begin{array}{c}2.779 \\
3459.351 \\
3462.130\end{array}$ & $\begin{array}{l}9.611 \\
3.191\end{array}$ & $\begin{array}{c}3 \\
1074 \\
1077\end{array}$ & 0.287 & 0.835 \\
\hline Spatial & $\begin{array}{l}\text { Between Groups } \\
\text { Within Groups } \\
\text { Total }\end{array}$ & $\begin{array}{c}19.833 \\
3427.020 \\
3446.833 \\
\end{array}$ & $\begin{array}{l}6.611 \\
3.191\end{array}$ & $\begin{array}{c}3 \\
1067 \\
1072 \\
\end{array}$ & 2.072 & 0.102 \\
\hline Intra-personal & $\begin{array}{l}\text { Between Groups } \\
\text { Within Groups } \\
\text { Total }\end{array}$ & $\begin{array}{c}24.857 \\
4278.112 \\
4302.969 \\
\end{array}$ & $\begin{array}{l}8.286 \\
4.002\end{array}$ & $\begin{array}{c}3 \\
1066 \\
1067 \\
\end{array}$ & 2.070 & 0.102 \\
\hline Linguistic & $\begin{array}{l}\text { Between Groups } \\
\text { Within Groups } \\
\text { Total }\end{array}$ & $\begin{array}{c}21.484 \\
3818.285 \\
3339.769\end{array}$ & $\begin{array}{l}7.161 \\
3.582\end{array}$ & $\begin{array}{c}3 \\
1066 \\
1069\end{array}$ & 1.999 & 0.112 \\
\hline All Question & $\begin{array}{l}\text { Between Groups } \\
\text { Within Groups } \\
\text { Total }\end{array}$ & $\begin{array}{c}10.254 \\
2512.899 \\
2523.152\end{array}$ & $\begin{array}{c}3.418 \\
2.327 \\
-\end{array}$ & $\begin{array}{c}3 \\
1080 \\
1083\end{array}$ & 1.469 & 0.221 \\
\hline
\end{tabular}

Table 4a: Post Hoc Analysis for the Differences in the Adjusted Mean Scores for the Students' Intelligence (logical/Mathematical) According to their GPA

\begin{tabular}{|c|c|c|c|c|}
\hline $\begin{array}{c}\text { GPA } \\
\text { Mean } \\
\end{array}$ & $\begin{array}{l}\text { poor } \\
6.17 \\
\end{array}$ & $\begin{array}{r}\text { good } \\
6.24 \\
\end{array}$ & $\begin{array}{c}\text { Very good } \\
6.58 \\
\end{array}$ & $\begin{array}{c}\text { excellent } \\
6.89 \\
\end{array}$ \\
\hline $\begin{array}{ll}\text { poor }^{\mathrm{t}} & 6.17 \\
\end{array}$ & - & -.07 & -.41 & $-.72 *$ \\
\hline good 6.24 & .07 & - & -.34 & $-.65 *$ \\
\hline Very good 6.58 & .41 & .34 & - & -.31 \\
\hline excellent 6.89 & $.72 *$ & $.65^{*}$ & .31 & - \\
\hline
\end{tabular}

*. The mean difference is significant at the .050 level. 
The post hoc analysis above shows that there is a trend as GPA increases, the logical/mathematical intelligence increases. This indicates the positive relationship between the student's academic achievements and his intelligence. However, high GPA does not always indicate student's intelligence. Further, one could say that having studied many courses, students develop their intelligence and polish their critical and creative thinking.

5. Are there statistical significant differences in Multiple Intelligences according to the academic year?

In order to find the differences in multiple intelligences according to the students' level of study (academic year), Post Hoc Analysis was conducted. The results of analysis revealed that there were significant differences in the musical intelligence in favor of the graduates. In other words, the level of study has no effect on students' intelligences except for the musical intelligence. Table (5) shows the results of Post Hoc Analysis (Scheffe) for the differences in the mean scores for the students in Multiple Intelligence Test according to the academic year.

Table 5: ANOVA analysis for the Differences in the Mean Scores for the Students responses According to their level of study

\begin{tabular}{|c|c|c|c|c|c|c|}
\hline Domain & $\begin{array}{l}\text { Source of } \\
\text { variance }\end{array}$ & $\begin{array}{c}\text { Sum of } \\
\text { Squares }\end{array}$ & $\begin{array}{c}\text { Mean } \\
\text { Squares }\end{array}$ & Df & F-value & Significance \\
\hline Logical /Mathematical & $\begin{array}{l}\text { Between Groups } \\
\text { Within Groups } \\
\text { Total }\end{array}$ & $\begin{array}{r}17.218 \\
4190.431 \\
4207.649\end{array}$ & $\begin{array}{l}4.304 \\
3.120\end{array}$ & $\begin{array}{c}4 \\
1343 \\
1347\end{array}$ & 1.380 & .239 \\
\hline Musical & $\begin{array}{l}\text { Between Groups } \\
\text { Within Groups } \\
\text { Total }\end{array}$ & $\begin{array}{r}72.313 \\
4954.805 \\
5027.118\end{array}$ & $\begin{array}{c}18.078 \\
3.689\end{array}$ & $\begin{array}{c}4 \\
1343 \\
1347 \\
\end{array}$ & 4.900 & .001 \\
\hline Interpersonal & $\begin{array}{l}\text { Between Groups } \\
\text { Within Groups } \\
\text { Total }\end{array}$ & $\begin{array}{r}13.557 \\
5356.850 \\
5370.407\end{array}$ & $\begin{array}{l}3.389 \\
4.007\end{array}$ & $\begin{array}{c}4 \\
1337 \\
1341\end{array}$ & .846 & .496 \\
\hline Physical/Bodily Kinetics & $\begin{array}{l}\text { Between Groups } \\
\text { Within Groups } \\
\text { Total }\end{array}$ & $\begin{array}{r}2.282 \\
4302.188 \\
4304.470\end{array}$ & $\begin{array}{c}.571 \\
3.220\end{array}$ & $\begin{array}{c}4 \\
1336 \\
1340\end{array}$ & .177 & .950 \\
\hline Spatial & $\begin{array}{l}\text { Between Groups } \\
\text { Within Groups } \\
\text { Total }\end{array}$ & $\begin{array}{r}15.918 \\
4332.048 \\
4347.966\end{array}$ & $\begin{array}{l}3.980 \\
3.240\end{array}$ & $\begin{array}{c}4 \\
1337 \\
1341\end{array}$ & 1.228 & .297 \\
\hline Intra-personal & $\begin{array}{l}\text { Between Groups } \\
\text { Within Groups } \\
\text { Total }\end{array}$ & $\begin{array}{r}6.868 \\
5280.957 \\
5287.825\end{array}$ & $\begin{array}{l}1.717 \\
3.965\end{array}$ & $\begin{array}{c}4 \\
1332 \\
1336\end{array}$ & .433 & .785 \\
\hline Linguistic & $\begin{array}{l}\text { Between Groups } \\
\text { Within Groups } \\
\text { Total }\end{array}$ & $\begin{array}{r}11.514 \\
4726.775 \\
4738.290\end{array}$ & $\begin{array}{l}2.879 \\
3.559\end{array}$ & $\begin{array}{c}4 \\
1328 \\
1332\end{array}$ & .809 & .520 \\
\hline All Question & $\begin{array}{l}\text { Between Groups } \\
\text { Within Groups } \\
\text { Total }\end{array}$ & $\begin{array}{r}3.773 \\
3143.849 \\
3147.622 \\
\end{array}$ & $\begin{array}{c}.943 \\
2.341\end{array}$ & $\begin{array}{c}4 \\
1343 \\
1347 \\
\end{array}$ & .403 & .807 \\
\hline
\end{tabular}

Table 5a: Post Hoc Analysis for the Differences in the Adjusted Mean Scores

for the Students' Intelligence (musical) According to the academic year

\begin{tabular}{|c|c|c|c|c|c|}
\hline $\begin{array}{r}\text { Year } \\
\text { Mean } \\
\end{array}$ & $\begin{array}{c}1^{\text {st }} \\
6.08\end{array}$ & $\begin{array}{l}2^{\text {nd }} \\
6.11\end{array}$ & $\begin{array}{l}3^{\text {rd }} \\
6.16 \\
\end{array}$ & $\begin{array}{c}4^{\text {th }} \\
5.94\end{array}$ & $\begin{array}{c}\text { More than } 4 \\
5.11 \\
\end{array}$ \\
\hline $1^{\text {st }} 6.08$ & - & -.04 & -.08 & .14 & $.97 *$ \\
\hline $2^{\text {nd }} 6.11$ & .03 & - & -.05 & .17 & $1.01 *$ \\
\hline $3^{\text {rd }} 6.16$ & .08 & .05 & - & .22 & $1.05 *$ \\
\hline $4^{\text {th }} 5.94$ & -.14 & -.17 & -.22 & - & $.83 *$ \\
\hline More than 45.11 & $-.97 *$ & $1.01 *$ & $-1.05 *$ & $-.83^{*}$ & - \\
\hline
\end{tabular}

*. The mean difference is significant at the .050 level. 
The Post Hoc analysis above shows that the students, during the first four years, have the same level with regard to the musical intelligence. However, after the fourth year, we find that there is a significant difference in the musical intelligence level for the favor of students who passed four years. This difference might be due to the fact that the stress and the load of courses has been reduced when they finish four years and consequently, students enjoy their time by listening to music and appreciating melodies and words of songs.

\section{CONCLUSIONS AND RECOMMENDATIONS}

The study has revealed that interpersonal intelligence is the highest and the most common intelligence among Jordanian students. Following are intra-personal, kinesthetic, linguistic, spatial, logicallmathematical and musical intelligences, respectively. This indicates the ability of students to understand themselves, needs and interests. Therefore, they will be able to establish good relationship with others in the university and society.

The logical intelligence is found the least common among Jordanian students who study in private universities due to the fact that they have low averages and thus they join private university. On the other hand, students with high averages join public university and are expected to score higher levels of logical intelligence than their counterparts in the private universities.

The females are better than the males with regard to the intra-personal and linguistic performance due to the nature and the way of bringing up the females in the Arabian society in general and Jordanian society in particular. Females spend almost their time at home with mothers and sisters and engage in daily chat the thing that develops their linguistic intelligence unlike males. Besides, because almost all Arabian families care about bringing up girls in a specific way (according to values and norms of Islam and traditions) girls grow up with ability to understand themselves and people around.

Concerning the relationship between GPA and types of intelligence, the study has revealed that high GPA associates with having a high level of logical/mathematical intelligence. However, one could safely say that this is not always the case but it indicates some sort of positive relationship between the GPA and logical intelligence.

The Musical intelligence is revealed to be developed in latter stages of study, i.e., after the fourth year where the load and stress of the courses and study is reduced. Students then tend to enjoy themselves by listening to music and mitigate the burden of study. However, students who study in prior stages (1-3) tend to be busy with study and may have no time to appreciate music and enjoy it and thus they do not develop their musical intelligence as their counterparts in later years of study (4-5).

This study showed that students are heterogeneous in their dominant types of intelligences. The findings of this study are consistent with Loori (2005), Yuen and Furnham (2005) and Netoa, Ruiza and Furnhamb (2008). There were significant differences among Jordanian students in the linguistic and intra-personal intelligences in favor of the females. There were significant differences in the logical intelligences in favor of the governmental universities. There were no significant differences in the multiple intelligences that can be attributed to the averages of the students. There were significant differences in the musical intelligence in favor of the graduates.

\section{RECOMMENDATIONS}

The findings of the present study may give insights to instructors, administrator, curriculum developer and even families to detect the type of intelligence the students have and try to promote and strengthen it to come to better results for the student himself and the whole society around. When considering the findings of this study, instructor can design a learning environment that enhances the intelligence of any student in the class by knowing his needs, interests and most of all his/her intelligence. The use of problem-solving skills that incorporate the eight types of intelligence could promote the use of the various intelligences. The researchers recommend doing further studies concerning multiple intelligences among students and how we can enhance them when designing a learning environment. Further, they recommend incorporating all types of intelligences in their pedagogy as to meet the individual differences among students concerning the issue in question. 


\section{AUTHOR INFORMATION}

Oraib. H. Al-Faoury, a lecturer of English communication skills at the University of Jordan and Philadelphia University, a lecturer of methodology at the University of Jordan, a lecturer of Arabic communication skills for speakers of other languages at Philadelphia University, a qualified trainer of ESOL in Business and Development Center, a trainer of functional grammar at Philadelphia University, a lecturer of creative writing, conversation and drama at Al-Riady Center for Excellent and Gifted Students and an international representative for Jordan in the field of child rights. I have published a research paper about the Effect of Teaching CORT 4 entitled creativity on the gifted Learners' critical reading. My research papers are directed towards creative short stories, multiple intelligences and giftedness. My current research paper is directed on the effect of an integrative skills program on developing Jordanian students' achievement in English and select multiple intelligences. E-mail oraibfa2007@yahoo.com. Corresponding author.

Abdalla .M. Khataybeh, Professor in science education at Yarmouk University. I have published more than fifty research papers and supervised about seventy M.A and $\mathrm{PhD}$ students. My research is directed towards constructivism in science education and authentic assessment in science education. We are conducting an project with EU to train science school teachers and students in Inquiry and problem solving in collaboration with other countries. As former dean of Faculty of humanities and Social Sciences at Sohar University in Oman I have established this faculty and prepared more than ten academic programs. I have chaired an accreditation committee to accreditation of the faculty of education at Jordan University. E-mail: drkhataybah@yahoo.com

Kholoud Al-Sheikh, Assistant professor in Science education at King AbdulAziz University. My unifying theme research efforts were conducting experimental field-testing to develop an instructional material for scientific issues according to Science, Technology and Society Curriculums such as Biofuel, Herbal Medicine and stem cells. My current research efforts are dedicated to develop teaching strategies as creative thinking and persuasion method. She has experience in jugging scientific project for many private and public Saudi universities. I joined workshops in Harvard, George mason and Melbourne University. As a deputy dean of quality assurance my experience extends as well in quality assurance and accreditation for academic courses and programs.

\section{REFERENCES}

1. Baş, G. (2010). Effects of Multiple Intelligences Approach in English Classes on Students' Academic Achievement Levels and Attitudes towards Lesson. E-Journal of New World Sciences Academy, 5(2), 411430.

2. Chen, J.Q. (2004). Theory of multiple intelligences: is it a scientific theory? Teachers College Record, 106, 17-23.

3. Eisner, E.W. (2004). Multiple intelligences: its tensions and possibilities. Teachers College Board, 106, 3139.

4. $\quad$ Ev Akademi Dergisi yil, 40 (13), 51-68.

5. Eski, G. (2009). Multiple Short Story Activities for Very Young Learners with Multiple Tastes. Ek.

6. Fink, L. (1991). Teaching and Assessing Using Multiple Intelligences Theory: A Classroom- based action Research Study. Unpublished Dissertation. University of Missouri.

7. Gardner, H. (1983). Frames of Mind. New York: Basic Books.

8. Gardner, H. (1993a). Multiple intelligences: The theory in practice. New York: Basic Books.

9. Gardner, H. (1993 b). Frames of Mind: The theory of multiple intelligences. 2nd ed. New York: Basic Books.

10. Gardner, H. (1999). Intelligence Reframed. Multiple Intelligences for the 21 st century. New York: Basic Books.

11. Gardner, H. (2004). A multiplicity of intelligences: In tribute to Professor Luigi Vigno. [Online] Available: http://www.howardgardner.com/Papers/ documents/T-101\%20A\%20Multiplicity\%20REVISED.pdf (May 2, 2007).

12. Gunst, G. (2004). A Study of Multiple Intelligences among Teachers in Catholic Elementary Schools in the Archdiocese of Detroit. Unpublished Dissertation. Wayne State University- Detroit, Michigan. 
13. Gürbüz \& Gürbüz (2010). Determination of Preschool Children's Dominant and Non-dominant Types of Intelligences with Regard to "THE Theory of Multiple Intelligences": A Qualitative Evaluation. E-Journal of New World Sciences Academy, 5 (2), 456-470.

14. Loori, A.A. (2005). Multiple intelligences: A comparative study between the preferences of males and females. Social Behavior and Personality, 33, 77-88.

15. Nataša, B. (2010). Multiple Intelligences Theory- A Milestone Innovation in English Language Teaching at the University of Nis Medical School. Acta Medica Medianae, 49(2), 15-19.

16. Netoa, Ruiza and Furnhamb. (2008). Sex differences in self-estimation of multiple intelligences among Portuguese adolescents. High Ability Studies, 19 (2), 189-204.

17. Wallace. (2010). The Perceptions of Community College Students to Foreign LANGUAGE Acquisition Grounded in Multiple Intelligence Theory. Unpublished dissertation, Capella University, USA.

18. Waterhouse, L. (2006). Inadequate evidence for multiple intelligences, Mozart effect and emotional intelligence theories. Educational Psychologist, 41, 247-255.

19. Wu and Alrabah (2009). A cross-cultural study of Taiwanese and Kuwaiti EFL students' learning styles and multiple intelligences. Innovations in Education and Teaching International, 46(2), 393-403.

20. Yuen and Furnham (2005). Sex differences in self-estimation of multiple intelligences among Hong Kong Chinese adolescents. High Ability Studies, 16(2), 187-199 